\title{
KEBIJAKAN PENGEMBANGAN SUMBER DAYA PERIKANAN BERKELANJUTAN DAN BERPERSPEKTIF MITIGASI BENCANA DI PADANG SUMATERA BARAT
}

\author{
${ }^{1}$ Tomi Ramadona, Tridoyo Kusumastanto dan Achmad Fahrudin \\ ${ }^{1}$ Sekolah Pasca Sarjana Magister sains Ekonomi Sumberdaya Kelautan Tropika \\ Institut Pertanian Bogor \\ Email: tomiramadona@ymail.com
}

Diterima 7 September 2012 - Disetujui 23 November 2012

\begin{abstract}
ABSTRAK
Penelitian yang bertujuan untuk merumuskan arahan kebijakan pengembangan sumber daya perikanan yang berkelanjutan dan berperspektif mitigasi bencana telah dilakukan di Kota Padang Tahun 2012. Metode penelitian menggunakan pendekatan sensus. Data yang dikumpulkan terdiri dari data primer dan skunder. Pengambilan data dilakukan secara purposive sampling. Responden terdiri dari nelayan yang mendaratkan ikan di Pelabuhan Perikanan Samudera (PPS) Bungus dengan komoditas tuna. Metode analisis data menggunakan analisis bioekonomi, kelayakan investasi, Analytical Hierarchy Process (AHP) dan analisis kelembagaan. Hasil penelitian menunjukkan bahwa sub-sektor perikanan memberikan pengaruh cukup besar bagi perekonomian Kota Padang. Pemanfaatan sumber daya tuna masih berada dibawah optimalnya. Pengelolaan optimal tuna dengan menggunakan rezim pengelolaan Maximum Equilibrium Yied (MEY) dengan discount rate sebesar 16\% yaitu dengan meningkatkan upaya sebesar 133 trip dan produksi sebesar 418,53 ton. Potensi bencana terbesar di Padang yang berdampak pada perikanan yaitu gempa bumi. Dari hasil penelitian tersebut menunjukkan bahwa arahan kebijakan yang tepat untuk diterapkan di Kota Padang yaitu mengembangkan sarana dan prasarana perikanan yang berperspektif mitigasi bencana dengan mempertimbangkan karakteristik masyarakat lokal dan kondisi daerah serta meningkatkan partisipasi pemangku kepentingan dalam rangka optimasi produktivitas perikanan yang berkelanjutan.
\end{abstract}

Kata Kunci: kebijakan, sumberdaya perikanan, bioekonomi, keberlanjutan, mitigasi bencana

\section{Abstract: Development Policies for Sustainable Fishery Resources with Disaster Mitigation Prespective in Padang, West Sumatra. By: Tomi Ramadona, Tridoyo Kusumastanto and Achmad Fahrudin.}

Research purposed to formulate the orientation of policy of sustainable fishery resources development with disaster mitigation perspective has been conducted in 2012. Method of the study was census approach. Data consists of primary and secondary data. Data were collected by purposive sampling. Respondents were fishers who landed their fishes at the Ocean Fishing Port (PPS) Bungus with tuna commodity. Analysis data method employs bio-economy analysis of investment feasibility, Analytical Hierarchy Process (AHP), and institutional analysis. Results showed that fishery sub-sector gave significant impact for the economy of Padang City. Utilization of tuna resource was still under its optimum value. Optimum tuna management using Maximum Equilibrium Yield (MEY) management regime with rate discount $16 \%$ was done by increasing effort to 133 trips and production to 418,53 tons. Most potential disaster in Padang influencing fishery sector was earthquake. Research showed that proper policy implemented in Padang was to develop fishery infrastructure with disaster mitigation perspective by considering local society characteristics and regional condition as well as by increasing stakeholder participation in order to optimize sustainable fishery productivity.

Keywords: policy, fishery resources, bioeconomic, sustainable, disaster mitigation 


\section{PENDAHULUAN}

Indonesia merupakan negara kepulauan dengan lebih dari 17.000 pulau, serta garis pantai terpanjang ke-empat di dunia yaitu 95.181 km (World Resources Institute, 2001). Berdasarkan Konvensi Hukum Laut (UNCLOS) tahun 1982, Indonesia memiliki kedaulatan atas wilayah perairan seluas 3,2 juta $\mathrm{km}^{2}$ yang terdiri dari perairan kepulauan seluas 2,9 juta $\mathrm{km}^{2}$ dan laut teritorial seluas 0,3 juta $\mathrm{km}^{2}$. Selain itu Indonesia juga mempunyai hak eksklusif untuk memanfaatkan sumber daya kelautan dan berbagai kepentingan terkait seluas 2,7 juta $\mathrm{km}^{2}$ pada perairan ZEE. Sebagai bagian dari potensi bidang kelautan, sektor perikanan memberikan kontribusi yang penting bagi perekonomian Indonesia, yaitu penghasil protein, tenaga kerja dan pendapatan (Kusumastanto dan Jolly, 1997).

Sebagai negara kepulauan terbesar di dunia, Indonesia berada pada pertemuan tiga lempeng utama dunia yakni lempeng Indo-Australia, Eurasia dan Pasifik. Fakta ini membuat Indonesia sangat berpotensi dilanda gempa bumi dan berujung tsunami. Kondisi ini diperparah dengan posisi Indonesia yang berada di jalur cincin api pasifik yang terkenal sebagai jalur rangkaian gunung api paling aktif di dunia. Tidak kurang dari 240 buah gunung berapi berada di Indonesia dimana 70 diantaranya dikategorikan aktif (Budiman, 2010). Bencana alam lainnya yang seringkali melanda Indonesia adalah longsor, angin topan, banjir dan tsunami.

Bagian barat pantai Sumatera merupakan daerah rawan gempa bumi yang mempunyai titik-titik gempa berada di dasar laut. Kondisi ini dapat mengakibatkan patahan di dasar laut yang akan menimbulkan gelombang yang sangat besar. Kota Padang termasuk dalam kawasan yang rawan dilanda bencana gempa dan tsunami yang pada dasarnya adalah kawasan pantai. Selain gempa dan tsunami masih terdapat potensi bencana pesisir lain di wilayah ini, dimana secara langsung maupun tidak langsung dapat mempengaruhi perkembangan sumber daya perikanan.
Kota Padang merupakan wilayah dengan karakteristik perikanan yang kompleks, pada satu sisi mempunyai potensi perikanan laut yang potensial dan di sisi lain dihadapkan pada kondisi daerah yang rawan bencana. Kondisi ini menuntut suatu kebijakan yang diharapkan mampu menyelesaikan permasalahan dalam hal pengembangan sumber daya perikanan baik oleh faktor internal maupun eksternal. Potensi perikanan melahirkan program pengelolaan dan pengembangan, sementara potensi bencana menuntut adanya tindakan mitigasi. Untuk itu, dalam pengambilan kebijakan terkait kondisi ini, perlu mempertimbangkan faktor pemerintah dan masyarakat.

Ibu kota Provinsi Sumatera Barat ini terletak di kawasan pesisir pantai barat Sumatera yang berhadapan langsung dengan Samudera Indonesia, yang memiliki perairan laut seluas $720 \mathrm{~km}^{2}$ dengan panjang pantai $68,126 \mathrm{~km}$. Potensi sub-sektor perikanan laut merupakan lapangan usaha yang mempunyai prospek sangat bagus untuk dikembangkan. Pada tahun 2006, jumlah tangkapan sebanyak 13.239 ton, sedangkan pada tahun 2008 diperoleh sebanyak 15.686 ton dan di tahun 2010 produksi mencapai 18.098 ton. Untuk produksi ikan tuna sendiri, Kota Padang pada tahun 2010 menghasilkan sebanyak 3.787 ton dengan nilai sebesar Rp. 70,06 milyar dari total Rp 251,20 miliar seluruh produksi perikanan laut (Dinas Kelautan dan Perikanan Kota Padang, 2011).

Kerusakan akibat bencana alam telah meningkat pesat selama beberapa dekade terakhir (Millennium Ecosystem Assessment dalam Costanza dan Farley, 2007), sebagian besar kerusakan ini terkonsentrasi di pantai. Kajian terhadap berbagai bencana alam di Indonesia telah mengemukakan kesimpulan bahwa kemerosotan kualitas lingkungan dan ketidaksiapan pemerintah serta masyarakat mengakibatkan kerugian yang sangat besar dan menghambat kegiatan ekonomi. Kondisi Kota Padang dengan potensi sumber daya perikanan yang cukup besar, namun dihadapkan pada permasalahan lokasi yang rawan bencana membutuhkan sebuah arahan 
kebijakan yang efektif guna mengembangkan sumberdaya perikanan yang berkelanjutan dan berperspektif mitigasi bencana.

\section{METODOLOGI}

\section{Lokasi dan Waktu Penelitian}

Penelitian ini dilaksanakan di Kota Padang Provinsi Sumatera Barat pada bulan April sampai dengan Juni 2012.

\section{Metode Pengumpulan Data}

Data yang digunakan dalam penelitian ini berupa data primer dan sekunder. Pengambilan data primer meliputi stuktur biaya dari usaha penangkapan ikan serta pola usaha perikanan dan wilayah tangkapan yang diperoleh dengan metode wawancara kepada nelayan untuk kebutuhan analisis bioekonomi. Sementara data untuk analisis deskriptif mencakup telaah proses kebijakan, program kebijakan dan manfaatnya bagi nelayan, biaya dan hasil tangkapan sebelum dan sesudah kebijakan, serta informasi terkait bencana dan mitigasi. Sedangkan dalam analisis AHP, data primer diperoleh melalui wawancara dengan pakar terkait dengan dipandu kuesioner.

Data sekunder dalam penelitian ini berupa data urut waktu (time series) yang meliputi data produksi (landing) dan input yang digunakan (effort), harga per unit yaitu data yang diperoleh dari pengamatan pihak lain, harga ikan per-kilogram per-tahun dan Indek Harga Konsumen (consumers price index), perkembangan jumlah nelayan serta armada dan alat tangkap, biaya dari masing-masing alat tangkap, serta data pendukung lainnya yang diperoleh dari PPS Bungus Kota Padang. Data lainnya dalam penelitian ini berupa data kisaran biaya dan komponen investasi terkait prioritas bentuk mitigasi bencana dan usaha tuna longline. Dalam hal identifikasi kondisi bencana dibutuhkan data peta bencana, kesesuaian lahan, data mitigasi bencana serta data kebijakan atau UU terkait kebencanaan di Kota Padang yang diperoleh dari LPSDKP Bungus, BPBD Kota Padang, Bappeda Kota
Padang, BBMKG Maritim Teluk Bayur dan BPSPL Kota Padang.

\section{Metode Pengambilan Contoh}

Metoda pengambilan contoh yang digunakan dalam pengumpulan data pada penelitian ini adalah purposive sampling. Pada penelitian ini, nelayan yang menjadi responden adalah kelompok nelayan yang mendaratkan ikan di PPS Bungus dengan hasil tangkapan ikan dari jenis pelagis besar yaitu tuna. Teknik pengambilan contoh yang digunakan pada nelayan tuna (longliner) ialah sensus, dimana seluruh nelayan kapal longline yang mendaratkan ikan pada waktu penelitian dijadikan sampel. Selama periode penelitian tercatat 9 kapal longline mendaratkan ikan di PPS Bungus. Jumlah responden nelayan terhitung sebanyak 9 orang ditambah responden tidak langsung yang diperoleh berdasarkan data kuesioner KKP Ditjen Perikanan Tangkap PPS Bungus selama tahun 2011 sebanyak 22 armada longline (22 orang). Total untuk responden nelayan ialah 31 orang.Penentuan sampel untuk analisis AHP menggunakan teknik purposive sampling. Dalam tahap pengumpulan data, responden diberikan informasi yang rinci oleh peneliti. Responden adalah pakar yang memiliki kapasitas dalam mengambil keputusan terkait pengembangan perikanan Kota Padang dan mitigasi bencana di daerah ini. Metode purposive sampling ini menentukan para pakar yang dijadikan responden dalam menentukan bobot nilai dari kriteria kebijakan. Dalam penelitian ini jumlah responden pakar ialah sebanyak 10 orang yang terdiri dari kalangan akademisi, peneliti, praktisi dan birokrat pemerintahan.

\section{Metode Analisis Data}

\section{Analisis Kondisi Makro Perikanan}

Dalam rangka mengetahui kondisi makro perikanan, dilakukan beberapa analisis yaitu; (1) Analisis Shiftshare bertujuan untuk mengetahui kontribusi sektor perikanan terhadap perekonomian daerah, (2) Analisis 
Location Quotient untuk mengetahui tingkat basis sektor perikanan dalam pembangunan wilayah, (3) Analisis Minimum Requirement Approach untuk mengukur seberapa besar kekuatan sektor basis dengan mengukur base multiplier-nya.

\section{Analisis Bioekonomi}

Penilaian sumberdaya perikanan yang perlu diketahui adalah nilai estimasi tangkapan lestari dari stok ikan. Guna mengetahui nilai estimasi tangkapan lestari dilakukan estimasi dengan model kuantitatif. Produktifitas stok ikan dipengaruhi oleh faktor endogenous seperti faktor biologi, pertumbuhan, kelahiran, rekruitmen, kematian dan ruaya, serta faktor exogenous seperti iklim, bencana, dan aktifitas manusia berupa penangkapan, pencemaran yang dapat menyebabkan turunnya kualitas perairan berdampak rusaknya ekosistem perairan. Teknik untuk mengestimasi parameter biologi dari model surplus produksi adalah melalui pendugaan koefisien yang dikembangkan oleh Clarke, Yoshimoto, dan Pooley (1992) yang dikenal dengan metode CYP.

\section{Analisis Kelayakan Investasi}

Analisis kelayakan investasi diperhitungkan dengan membandingkan antara besarnya biaya yang dikeluarkan dengan manfaat yang diterima dalam suatu kegiatan investasi untuk jangka waktu tertentu. Dalam analisis kelayakan investasi terdapat beberapa kriteria investasi yang dilakukan yaitu: Net Present Value (NPV), Internal Rate of Return (IRR) dan Net B/C. Pada penelitian ini, analisis kelayakan investasi digunakan untuk menilai kelayakan usaha tuna longliner di Kota Padang dan investasi penggunaan sarana mitigasi terhadap usaha perikanan tangkap tersebut.

\section{Analisis Kelembagaan}

Analisis kelembagaan ini bertujuan untuk memotret situasi kelembagaan yang sudah ada. Selain proses pengumpulan data, analisis ini juga membahas hal-hal yang berkaitan dengan dimensi sosial ditinjau dari perspektif keberlanjutannya. Perspektif keberlanjutan dari dimensi sosial antara lain dengan melakukan analisis keadaan sosial serta atribut-atribut yang mempengaruhi keberlanjutan perikanan dari sisi sosial. Dalam rangka menentukan stakeholder yang benar-benar berkompeten dalam merumuskan strategi pengembangan sumber daya perikanan yang berkelanjutan dan berperspektif mitigasi bencana, digunakan stakeholder analysis yaitu suatu teknik yang digunakan untuk mengidentifikasi dan merujuk pihak (seseorang) yang tepat atau berpengaruh pada aktifitas suatu program.

\section{Analisis Proses Berjenjang (AHP)}

Analysis Hierarchy process (AHP) dilakukan untuk menentukan prioritas bentuk mitigasi serta potensi bencana yang berdampak langsung terhadap pengembangan sumberdaya perikanan. Prinsip dasar penyelesaian persoalan dengan metode AHP adalah decomposition,comparative judgement, synthesis of priority, dan logical consistency. Pada analisis ini, kriteria dan alternatif dinilai melalui perbandingan berpasangan. Menurut Saaty dalam Marimin (2004) untuk berbagai persoalan skala 1 sampai 9 adalah skala terbaik dalam mengekspresikan pendapat. Kemudian untuk memeriksa apakah perbandingan berpasangan telah dilakukan dengan konsekuen atau tidak digunakan parameter Consistency Ratio (CR). Kemudian untuk penyelesaian analisis ini dilakukan menggunakan aplikasi Criterium Decision Plus versi-30 (Marimin, 2004).

\section{Analisis Deskriptif}

Metoda analisis deskriptif yaitu metoda penelitian yang melakukan penuturan, analisis dan mengklasifikasikan data dan informasi yang diperoleh dengan berbagai teknik seperti survey, wawancara, observasi, angket, kuesioner, studi kasus, dan lain-lain (Surakhmad, 1978). Dalam hal ini, analisis deskriptif akan lebih difokuskan kepada analisis kebijakan terkait pengembangan perikanan dan mitigasi bencana. 


\section{PENGARUH SEKTOR PERIKANAN TERHADAP PEREKONOMIAN}

Melalui analisis Shift Share, Location Quotient dan MRA diketahui bahwa subsektor perikanan memberikan pengaruh yang berarti bagi perekonomian Kota Padang. Hal ini terbukti dari adanya peningkatan kontribusi dari tahun ke tahun, tren positif nilai LQ dan multiplier effect pada sektor lain.Fakta ini memberikan peluang terhadap arahan kebijakan pembangunan Kota Padang untuk mempertimbangkan sektor basis sebagai penyangga perekonomian daerah. Demikian juga halnya dengan analisis terkait prioritas pengembangan bidang kelautan, dimana hasil kajian mengemukakan bahwa perikanan menjadi alternatif terkuat bagi pembangunan perekonomian Kota Padang. Rekap perkembangan kontribusi sub sektor perikanan dalam kaitannya terhadap perekonomian daerah ditampilkan dalam Gambar 1, 2 dan Tabel 1 (Analisis MRA).

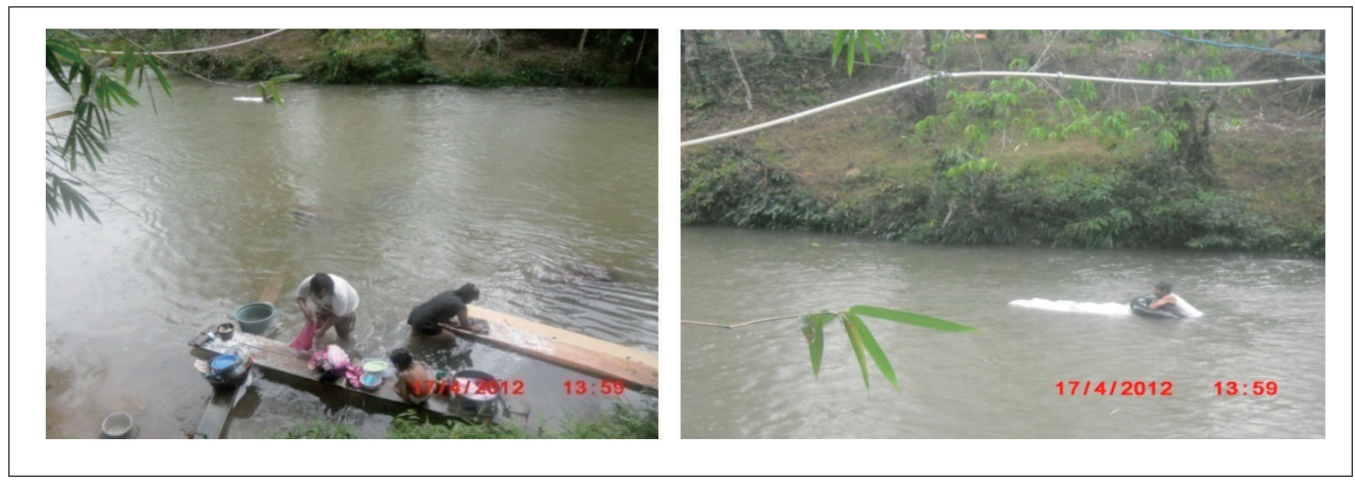

Gambar 1.Perkembangan Kontribusi (Analisis Shift Share)

Figure 1. Contribution Development (Shift Share Analysis)

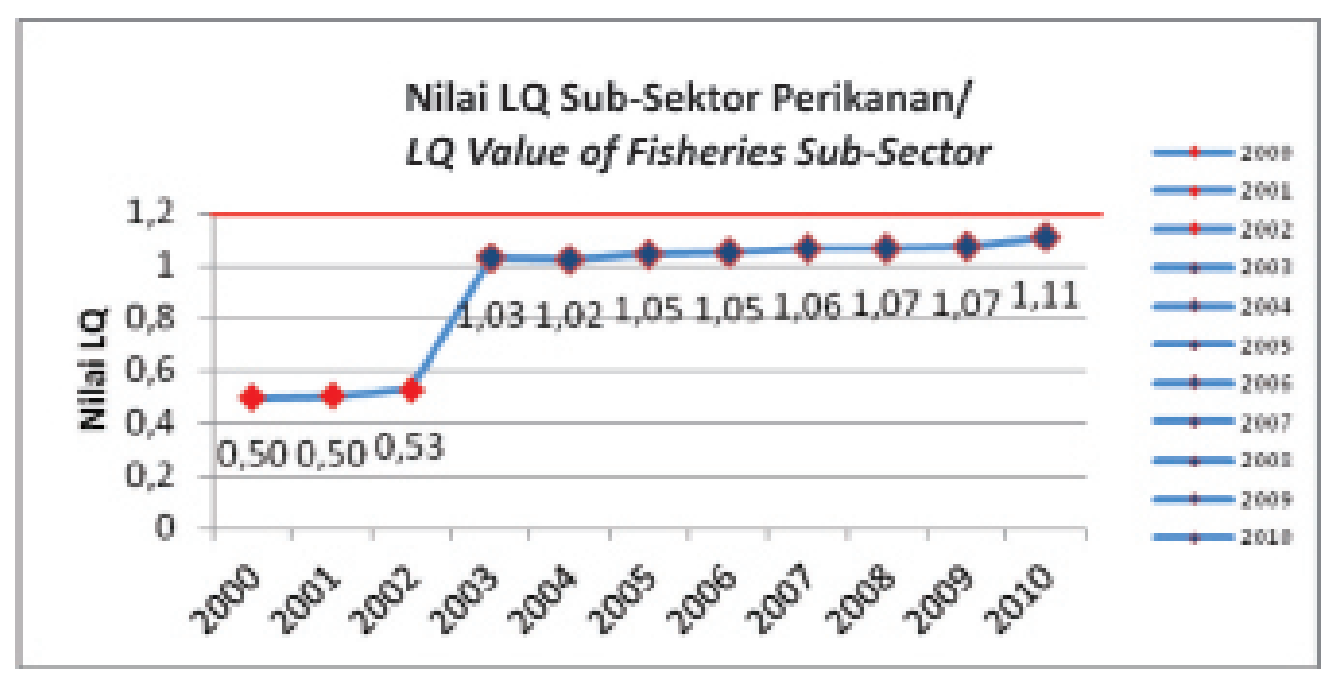

Gambar 2. Perkembangan Nilai LQ (Analisis Location Quotient)

Figure 2. LQ Value Development (Location Quotient Analysis) 
Tabel 1. Perhitungan MRA Sub-sektor Perikanan antar Wilayah Tahun 2010. Table 1. MRA Calculation of Regional Fisheries Sub-Sector in 2010.

\begin{tabular}{lllcrrrr}
\hline No. & Wilayah/Region & $\begin{array}{l}\text { Share } \\
\text { Sector }\end{array}$ & $\begin{array}{c}\text { Minimum } \\
\text { Shares Peer }\end{array}$ & $\begin{array}{c}\text { Total Emp. } \\
\text { Sektor }\end{array}$ & Total Emp. & Basic Emp. & $\begin{array}{c}\text { Basic } \\
\text { Multiplier }\end{array}$ \\
\hline 1 & Kota Padang & 0.003 & 0.003 & 6,898 & $1,998,922$ & 901,234 & $2,217.9$ \\
2 & Kota Pariaman & 0.048 & 0.003 & 1,177 & 24,635 & $1,103,095$ & 22.3 \\
3 & Kab. Pdg. Pariaman & 0.031 & 0.003 & 4,381 & 142,222 & $3,954,334$ & 35.9 \\
4 & Kab. Pesisir Selatan & 0.100 & 0.003 & 13,998 & 140,262 & $13,577,214$ & 10.3 \\
5 & Kab. Pasaman Barat & 0.018 & 0.003 & 2,762 & 157,742 & $2,288,774$ & 68.9 \\
6 & Kab. Kep. Mentawai & 0.122 & 0.003 & 3,216 & 26,468 & $3,136,596$ & 8.4 \\
\hline
\end{tabular}

Sumber : Data hasil olahan/Source: Data processed

\section{PERANAN IKAN TUNA DALAM PERIKANAN TANGKAP}

Perhitungan bioekonomi dalam penelitian ini adalah analisis pada jenis ikan tuna. Dipilihnya jenis ini disebabkan tuna merupakan komoditi utama perikanan tangkap Kota Padang yang menghasilkan kontribusi terbesar dibandingkan jenis lain. Selain itu, objek penelitian ini ialah spesies komoditas ekspor perikanan Kota Padang. Jenis spesies yang diteliti ialah Tuna Mata Besar/bigeye (Thunus obesus) dan Tuna Sirip Kuning/ yellowfin (Thunus albacares).
Data sekunder sebagai rujukan analisis data pada tahap ini diambil dari Pelabuhan Perikanan Samudera (PPS) Bungus Kota Padang yang juga merupakan sentra perikanan tuna Indonesia bagian barat Pendekatan analisis secara biologi dan ekonomi merupakan salah satu alternatif yang dapat diterapkan dalam upaya optimalisasi penguasaan sumber daya perikanan tangkap secara berkelanjutan. Pada Tabel 2 dan Tabel 3 ditampilkan hasil estimasi parameter biologi dan ekonomi sumber daya ikan tuna dan rezim pengelolaan sumber daya tuna.

Tabel 2. Hasil Estimasi Parameter Biologi dan Ekonomi Sumber daya Ikan Tuna.

Table 2. Estimation Result of Biology and Tuna Resource Economics Parameter.

\begin{tabular}{ccccc}
\hline \multicolumn{5}{c}{ Parameter } \\
\hline $\mathbf{r}$ (ton/trip) & $\mathbf{q}$ (ton/unit) & $\mathrm{K}$ (ton) & $\mathbf{p}$ (price, jt Rp/ton) & $\mathrm{c}$ (cost, jt Rp/trip) \\
\hline 2,642119465 & 0.005323825 & $1,676.68$ & 47.43 & 38.86 \\
\hline
\end{tabular}

Sumber : Data hasil olahan/Source: Data Processed

Tabel 3. Hasil Analisis Bioekonomi dalam Berbagai Rezim Pengelolaan Sumberdaya Ikan Tuna. Table 3. Results of Bioeconmy Analysis in Different Tuna Resources Management Regime.

\begin{tabular}{crrrrrr}
$\begin{array}{c}\text { Variabel Kendali/ } \\
\text { Control Variable }\end{array}$ & $\begin{array}{c}\text { Sole Owner } \\
\text { /MEY }\end{array}$ & $\begin{array}{c}\text { Open } \\
\text { Access/ } \\
\text { OAY }\end{array}$ & MSY & $\begin{array}{c}\text { Optimal } \\
\text { Dynamic } \\
\text { (i=16) }\end{array}$ & $\begin{array}{c}\text { Optimal } \\
\text { Dynamic } \\
\text { (i=18) }\end{array}$ & $\begin{array}{r}\text { Aktual/ } \\
\text { Actual }\end{array}$ \\
\hline x (ton) & 915.28 & 153.89 & 838.34 & 876.46 & 872.03 & \\
h (ton) & $1,098.17$ & 369.27 & $1,107.49$ & $1,105.21$ & $1,105.71$ & 686.68 \\
E (trip) & 225 & 451 & 248 & 237 & 238 & 104 \\
$\pi$ (juta Rp) & $43,332.71$ & - & $42,890.17$ & $322,066.45$ & $288,621.83$ & $31,572.62$ \\
$\pi$ Overtime & & & & $5,172.22$ & $31,335.54$ & - \\
\hline
\end{tabular}

Sumber : Data hasil olahan/Source: Data processed 
Berdasarkan besaran nilai rente yang diperoleh, rezim pengelolaan sole owner atau MEY adalah nilai yang tertinggi jika dibandingkan dengan kondisi lainnya. Selain itu, pada MEY jumlah stok ikan diperairan menghasilkan jumlah yang paling banyak. Oleh karena itu, pengelolaan sumber daya perikanan di Kota Padang sebaiknya dikelola dengan rezim pengelolaan MEY. Melalui hasil estimasi parameter biologi dan ekonomi, diperoleh gambaran fungsi pertumbuhan logistik dan rezim pengelolaan sumber daya perikanan tuna yang ditampilkan pada Gambar 3 dan Gambar 4: nelayan, pembuatan peraturan, undangundang dan kebijakan lain terkait mitigasi bencana dan keberlanjutan sumber daya Perikanan.

\section{KELAYAKAN INVESTASI USAHA TUNA LONGLINE}

Melalui analisis kelayakan investasi terkait usaha tuna longliner dan penambahan sarana mitigasi ditampilkan pada Tabel 4.

Hasil analisis menunjukkan bahwa usaha penangkapan ikan menggunakan tuna longliner masih menguntungkan ditinjau dari

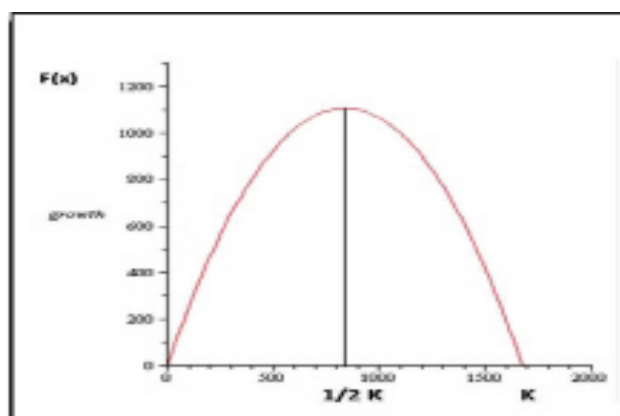

Gambar 3. Kurva Pertumbuhan Logistik Figure 3. Logistic Growth Curve

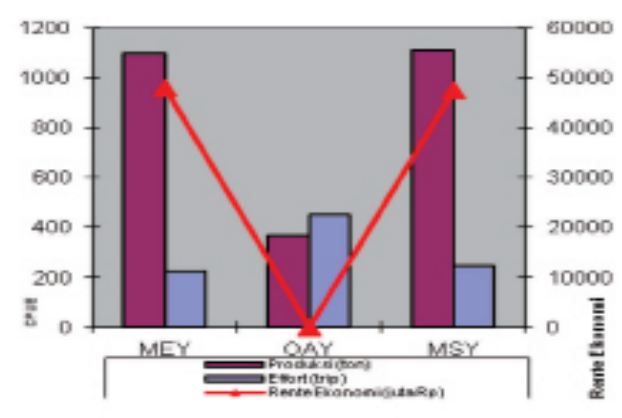

Gambar 4. Regim Pengelola SDI Tuna Figure 4. Tuna Resources Management Regime

\section{POTENSI BENCANA DAN PENGEMBANGAN PERIKANAN}

Berdasarkan hasil tabulasi kuisioner dan wawancara dengan pakar melalui metode ordinal AHP, diketahui bahwa secara spesifik jenis bencana yang berpotensi terjadi di Kota Padang terkait pengembangan perikanan adalah gempa bumi, tsunami, angin kencang, gelombang laut dan intrusi air laut, sementara bencana yang lain pengaruhnya tidak terlalu besar. Sedangkan mitigasi bencana terkait pengembangan perikanan yang perlu dikembangkan di Kota Padang antara lain; sistem peringatan dini dan sistem informasi terpadu, penyediaan GPS, APS dan aplikasi informasi bencana untuk indikator NPV, IRR dan Net B/C.

Demikian juga halnya dengan penambahan sarana mitigasi berupa paket GPS, radio komunikasi dan aplikasi selular yang masih memberikan keuntungan sehingga usaha ini masih layak untuk dikembangkan. Dalam rangka meningkatkan produktivitas perikanan tangkap perlu dilakukan beberapa upaya diantaranya melalui pemasangan rumpon laut dalam.

Usaha penangkapan ikan tuna menggunakan alat bantu rumpon hasilnya akan lebih baik, karena nelayan dapat menghemat biaya untuk pembelian bahan bakar sehingga biaya eksploitasi dapat ditekan (Wudianto et al., 2010). 
Tabel 4. Hasil Analisis Kelayakan Investasi.

Table 4. Results of Investment Feasibilty Analysis.

\begin{tabular}{lrlr}
\hline \multicolumn{2}{c}{$\begin{array}{c}\text { Pengembangan Perikanan/ } \\
\text { Fisheries Development } \\
\text { (Usaha Tuna longliner/ } \\
\text { Bussiness of Tuna Longliner) }\end{array}$} & $\begin{array}{c}\text { Pengembangan Perikanan Menggunakan Sarana } \\
\text { Mitigasi/Fisheries Development Using Mitigation } \\
\text { Facilities }\end{array}$ \\
\hline Parameter & Nilai/Value & Parameter & Nilai/Value \\
\hline NPV & Rp 1,132,235,510 & NPV & Rp 1,119,425,792 \\
IRR & $64.44 \%$ & IRR & $63.33 \%$ \\
Net B/C & 2.42 & Net B/C & 2.38 \\
\hline
\end{tabular}

Sumber : Data hasil olahan/Source: Data Processed

\section{PEMANGKU KEPENTINGAN TERKAIT PENGEMBANGAN PERIKANAN}

Kepentingan pemangku kepentingan dalam kebijakan pengembangan sumber daya perikanan yang berkelanjutan dipengaruhi oleh faktor ekologi, sosial dan ekonomi. Pengaruh pemangku kepentingan yang berbeda-beda dalam kebijakan ini disebabkan oleh faktor politik, birokrasi dan struktural. Pemangku kepentingan yang dianalisis dalam penelitian ini ialah segenap pemangku kepentingan yang berkaitan dengan programprogram pengembangan perikanan, baik berupa minapolitan, industri perikanan ataupun kebijakan lainnya dalam hal pengembangan perikanan. Pemangku kepentingan primer dalam pengembangan perikanan di Kota Padang adalah Kementerian Kelautan dan Perikanan (KKP), Dinas Kelautan dan Perikanan Kota Padang (DKP), Pemerintah Daerah Kota Padang (Pemda).

\section{PRIORITAS KEBIJAKAN PENGELOLAAN SUMBER DAYA PERIKANAN}

Melalui Analytical Hierarchy Process (AHP) diperoleh prioritas kebijakan pengelolaan sumber daya perikanan Kota Padang sebagaimana ditampilkan pada Gambar 6.

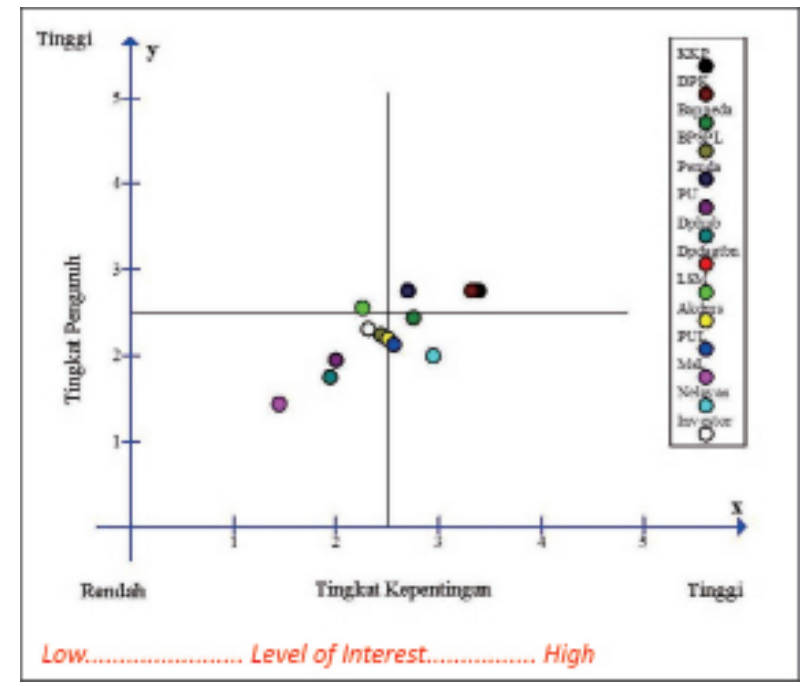

Gambar 5. Matriks Kepentingan dan Pengaruh Stakeholder dalam Pengembangan Perikanan yang Berkelanjutan di Kota Padang.

Picture 5. Matrix of Stakeholder Influence and Interest in Sustainabilty Fisheries Development, Padang. 


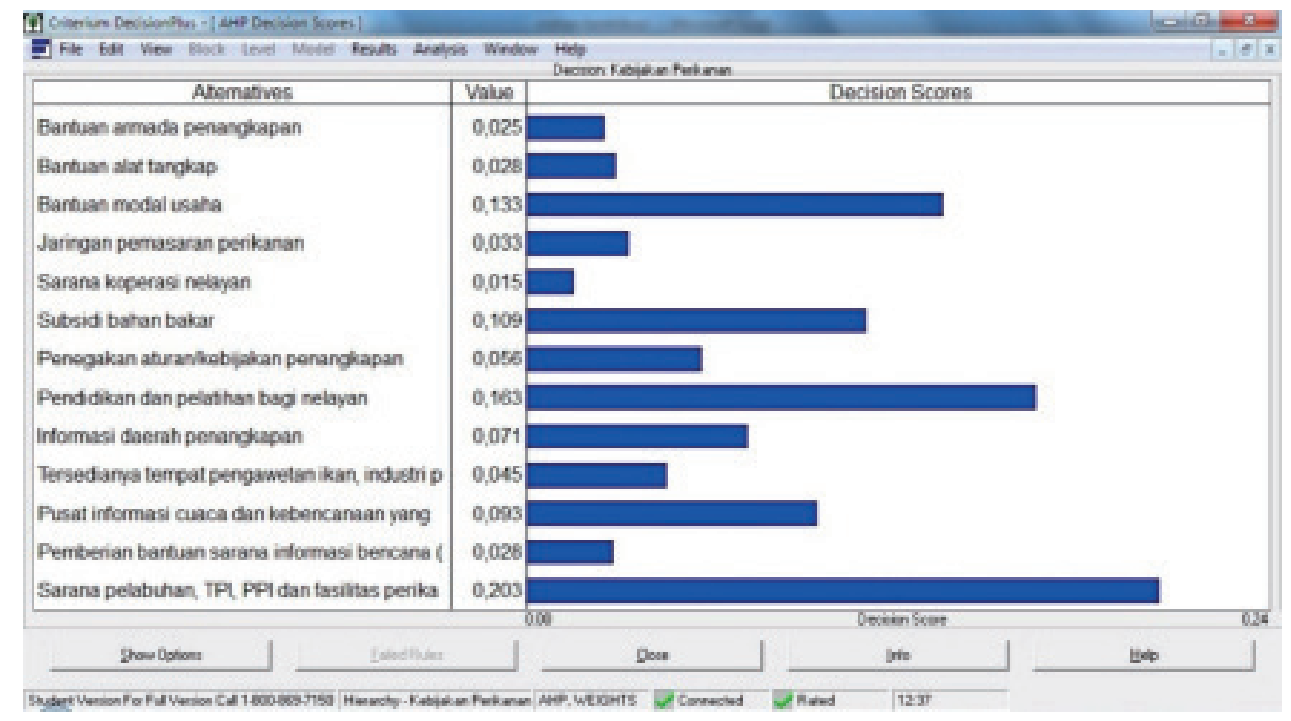

\section{Gambar 6. Hasil Penilaian AHP Prioritas Kebijakan Pengelolaan Perikanan. Picture 6. AHP Assesment of Fisheries Management Policy Priorities}

Beberapa alternatif kebijakan disusun dengan mempertimbangkan kondisi wilayah Kota Padang, yaitu potensi perikanan serta kondisi daerah yang rawan bencana. Prioritas kebijakan pengembangan perikanan di Kota Padang adalah:

1. Penyediaan sarana pelabuhan, TPI, PPI dan fasilitas perikanan lainnya yang kondusif dan berperspektif mitigasi bencana.

2. Pendidikan dan pelatihan bagi nelayan.

3. Bantuan modal usaha bagi nelayan serta masyarakat yang ingin mengembangkan usaha perikanan.

4. Subsidi bahan bakar dan Pusat informasi cuaca dan kebencanaan yang mudah diakses.

Rumusan arahan kebijakan pengembangan sumber daya perikanan yang berkelanjutan berperspektif mitigasi bencana di Kota Padang adalah: mengembangkan sarana dan prasarana perikanan yang berperspektif mitigasi bencana dengan mengedepankan karakteristik masyarakat lokal dan kondisi wilayah serta meningkatkan partisipasi stakeholder untuk mencapai co-management dalam rangka optimasi produktivitas sumberdaya perikanan dan optimasi perlindungan sistem penyangga kehidupan.

\section{PENUTUP}

Melalui serangkaian hasil analisis yang dilakukan dapat disimpulkan bahwa, subsektor perikanan memberikan pengaruh yang cukup besar bagi perekonomian Kota Padang, sehingga layak menjadi tulang punggung perekonomian daerah. Hal ini sejalan dengan hasil analisis prioritas pengembangan bidang kelautan, dimana perikanan merupakan sektor kelautan yang paling potensial untuk dikembangkan. Sumberdaya tuna merupakan komuditi unggulan Kota Padang, jumlah produksi masih dapat ditingkatkan sebesar 418,53 ton dengan penambahan effort sebanyak 133 trip.Usaha penangkapan menggunakan tuna longliner masih menguntungkan ditinjau dari indikator NPV, IRR dan Net B/C, demikian juga halnya dengan penambahan sarana mitigasi. Dalam rangka optimasi produktivitas sumberdaya perikanan dan perlindungan sistem penyangga kehidupan, perlu dukungan seluruh pemangku kepentingan untuk mencapai co-management sehingga tercapai kesejahteraan. Kebijakan yang 
berperspektif mitigasi bencana memiliki nilai. Nilai akan sangat berharga apabila segenap upaya dalam meningkatkan produksi dan keberlanjutan dihadapkan pada resiko bencana yang akan terjadi.

Dalam rangka pengembangan sumber daya perikanan yang berkelanjutan dan berperspektif mitigasi bencana, beberapa pertimbangan yang diperlukan antara lain:

1. Perlu dilakukan penelitian lebih lanjut terhadap strategi mitigasi bencana terhadap pengelolaan dan pengembangan perikanan serta efektifitas program programpengembangan perikanan yang berkelanjutan.

2. Pemerintah memiliki peran dalam mengelola dan merencanakan pengembangan perikanan yang optimal dan berkelanjutan.

3. Perlu harmonisasi seluruh institusi terkait pengaruh, kepentingan dan kebijakan dalam mendukung program pengembangan perikanan.

\section{DAFTAR PUSTAKA}

Budiman, C. 2010. Menata Kembali Relasi IImu Pengetahuan dan Bencana Alam. Inovasi Online. (XXII)18, November 2010. PPI Jepang.
Clarke, R.P., S.S. Yoshimoto and S.G. Pooley. 1992. A Bioeconomic Analysis of the Northwestern Hawaiian Islands Lobster Fishery. Marine Resource Economics. Vol. 7. 115-140pp. Printed in USA.

Constanza, R. and J. Farley. 2007. Ecological Economics of Coastal Disaster : Introduction to the Spesial Issue. J Ecological Economics.63 : 249 -253pp. Elsevier.

Dinas Kelautan dan Perikanan Kota Padang. 2011. Database Dinas Kelautan dan Perikanan Kota Padang. Padang.

Kusumastanto, T. and C.M. Jolly. 1997. Demand Analysis for Fish in Indonesia. J Applied Economics. 29 : 95-100pp. Routledge.

Marimin.2004. Teknik dan Aplikasi Pengambilan Keputusan Kriteria Majemuk. PT. Gramedia Widisarana Indonesia. Jakarta.

Surakhmad, W. 1978. Dasar dan Teknik Research : Pengantar Metodologi Ilmiah. Tarsito. Bandung.

United State Defense Mapping Agency. 2011. Coastline Length. World Vector Shoereline. United State Defense Mapping Agency.

Wudianto, Wijopriono dan F. Satria. 2010. Penelitian Jenis Alat Tangkap yang Sesuai untuk Menangkap Ikan Tuna di Sekitar Rumpon Laut Dalam. Laporan Akhir. BPPKP. KKP RI. Jakarta. 